\title{
On the Influence of Naturalism on American Literature
}

\author{
Xiaofen Zhang \\ Dezhou University, Dezhou 253023, China \\ E-mail: dzzxf369@163.com
}

\begin{abstract}
Naturalism was first proposed and formulated by French novelist Emile Zola, and it was introduced to America by American novelist Frank Norris. It is a new and harsher realism. It is a theory in literature emphasizing scientific observation of life without idealism or avoidance of the ugly. American literature naturalists dismissed the validity of comforting moral truths. They attempted to achieve extreme objectivity and frankness, presenting characters of low social and economic classes who were dominated by their environment and heredity. The pessimism and deterministic ideas of naturalism pervaded the works of such writers as Stephen Crane, Frank Norris, Jack London, Henry Adams, Theodore Dreiser, and Hemingway etc. This essay intends to deal with the application of naturalism in American literature and thereby seeks a broader understanding of naturalist literature in general.
\end{abstract}

Keywords: Naturalism, Influence, American literature

\section{Introduction of naturalism}

Webster's Dictionary gives naturalism a concise definition: A made of thought (religious, moral or philosophical) glorifying nature and excluding supernatural and spiritual elements close adherence to nature in art or literature, esp. (in literature) the technique, chiefly associated with Zola, used to present a naturalistic philosophy, esp. by emphasizing the effect of heredity and environment on human nature and action (The Webster's Dictionary of the English Language, 1989, p. 667). Naturalism was first proposed and formulated by Emile Zola, the French writer and theorist, who is universally labeled as the founder of literary naturalism. Naturalism was a literary movement taking place from 1865 to 1900 that used detailed realism to suggest that social conditions, heredity, and environment had inescapable force in shaping human character. Naturalistic writers were influenced by the evolution theory of Charles Darwin. They believed that one's heredity and social environment determine one's character and influence the actions of its subjects.

\section{Characteristics of naturalism}

Naturalism is a new and harsher of realism, The term naturalism itself came from Emile Zola. It is believed that he sought a new idea to convince the reading public of something new and more modern in his fiction. He argued that his innovation in fiction-writing was the creation of characters and plots based on the scientific method. Skinnerian principles of learning through conditioning and the Darwinian hierarchy of the survival of the fittest are the underlying themes involved in shaping the human character. There are many defining characteristics of literary naturalism.

\subsection{One of these of naturalism is determinism.}

Determinism is basically the opposite of the notion of free will. For determinism, the idea that individual characters have a direct influence on the course of their lives is supplanted by a focus on nature or fate. Human beings are living in a natural environment like animals. They can react toward the exterior and interior forces but they are helpless before these forces (Lin Xianghua, 1989, p.528). Often, a naturalist author will lead the reader to believe that a character's fate has been pre-determined, usually by heredity and environmental factors, that the destiny of humanity is misery in life and oblivion in death and that he/she can do nothing about it.

\subsection{Another characteristic of literary naturalism is objectivism.}

The author often tries to maintain a tone that will be experienced as 'objective.' The author presents himself or herself as an objective observer, similar to a scientist taking note of what he or she sees. Of course, no human being can ever be truly objective, but by detaching the narrator from the story he or she tells, an author can achieve objectivity. Also, an author will sometimes achieve detachment by creating nameless characters (strictly speaking, this is more common among modernists such as Ernest Hemingway). This puts the focus more on the plot and what happens to the character, rather than the characters themselves.

\subsection{Another characteristic is pessimism.}

Very often, one or more characters will continue to repeat one line or phrase that tends to have a pessimistic connotation, sometimes emphasizing the inevitability of death. Naturalistic works often include uncouth or 
sordid subject matter, for example, Emile Zola's works had a frankness about sexuality along with a pervasive pessimism. Naturalistic works exposed the dark harshness of life, including poverty, racism, sex, prejudice, disease, prostitution, and filth.

\subsection{Another common characteristic is a surprising twist at the end of the story.}

Equally, there tends to be in naturalist novels and stories a strong sense that nature is indifferent to human struggle.

\section{Influence of Naturalism on American literature}

Influenced by European naturalists, especially by Emile Zola, at the end of the nineteenth century, a generation of writers arose in America, whose ideas of the workings of the universe and whose perception of society's disorders let them to naturalism, a new and harsher realism.

\subsection{Jack London}

Jack London (1876-1916) was one of the most popular American writers of his time and regarded as one of the greatest naturalist novelists of America. He has been in the forefront of the move toward naturalistic fiction and realism in America. He has been deeply influenced by Darwin's ideas of constant struggle in nature and "the survival of the fittest. He shows his philosophy of naturalism completely in The Call of the Wild.

\subsubsection{The Summary of The Call of the Wild}

The Call of the Wild is a novel by Jack London. The plot concerns a previously domesticated and somewhat pampered dog named Buck, whose primordial instincts return after a series of events. One day he was kidnapped and taken to the north, where he served as a sled dog in the treacherous, frigid Yukon. The bad weather, the terrible Husky dogs, the fights, his dead friend and many things made Buck know he was surrounded by savages. There was no fair play. Only fight and war can help him. Finally, he began to master his new surroundings. His ability to rule and his great intelligence and good judgment were wonders to everyone. Then, Buck was sold once more. It was John Thornton who rescued him and became his new owner. But life was hard for Buck. When they lived in a forest, the Yeehats, an Indian tribe killed all the people, include John. Buck was very angry, and he killed most of the Yeehats. After John's death, Buck's last tie with people was broken. Finally, he was ready to answer the call of the wild. He ran with wolves, side by side with his wild brothers, shouted as he ran. He sounded the call of the wild. More and more cruelties make Buck realize there is no goodness and kindness in this world. There is only one rule: dead or kill; eat or be eaten off.

\subsubsection{Analysis of his work}

Environment plays a very important part in The Call of the Wild. By analyzing this novel we can see how environment controls one's (here dog's and wolf's) life. Zola said: "I still hold my view that the environment plays a very important part," "When we research a family or a group of people, I think the environment has a chief importance (Zola, 1988, p. 476)." Jack London has a deep understanding about environment, so we can clearly see many expressions of Naturalism in The Call of the Wild. As an animal, Buck's behaviors represent "the survival of the fittest. He made himself accustom to the new environment, so he won the right of survival. At the same time, Buck ensured himself the safety with his courage and wisdom in the severe north. As a symbol of human nature, Buck's behaviors indicated the extremely cruel and unfair humanity in misery and the hunger. He was struggling for his life. Facing trouble, to survive is the most important thing. From portraying the dog's images to revealing the formation and development of the dog's character, the novel embodies obviously genetic determinism and environmental determinism advocated by Zola. Darwin's theory of "the big fish eat up the small, the fittest survive is fully expressed through Buck's image.

\subsection{Theodore Dreiser}

THEODORE DREISER (1871-1945) was one of the outstanding American writers of naturalism. He was the leading figure in a national literary movement that replaced the observance of Victorian notions of propriety with the unflinching presentation of real-life subject matter. Among other themes, his novels explore the new social problems that had arisen in a rapidly industrializing America. Sinclair Lewis said in his Nobel Prize Lecture of 1930, that Dreiser's great first novel, Sister Carrie, which he dared to publish thirty long years ago and which I read twenty-five years ago, came to housebound and airless America like a great free Western wind, and to our stuffy domesticity gave us the first fresh air since Mark Twain and Whitman.

\subsubsection{The Summary of Sister Carrie}

Sister Carrie tells the story of a rudderless but pretty small-town girl who comes to the big city filled with vague ambitions. She is used by men and uses them in turn to become a successful Broadway actress while George 
Hurstwood, the married man who has run away with her, loses his grip on life and descends into beggary and in despair, commits suicide by gassing himself in his hotel room one night. Meanwhile, Carrie achieves stardom, but finds that money and fame do not satisfy her longings or bring her happiness and that nothing will.

\subsubsection{Analysis of his work}

Dreiser's first novel, Sister Carrie (1900), is a work of pivotal importance in American literature despite its inauspicious launching. It became a beacon to subsequent American writers whose allegiance was to the realistic treatment of any and all subject matter. With the publication of Sister Carrie in 1900, Dreiser committed his literary force to opening the new ground of American naturalism. His heroes and heroines, his settings, his frank discussion, celebration, and humanization of sex, his clear dissection of the mechanistic brutality of American society, all were new and shocking to a reading public reared on genteel romances and adventure narratives. Dreiser received a reputation as a naturalist-barbarian. he has cleared the trail from Victorian and Howellsian timidity and gentility in American fiction to honesty and boldness and passion of life. Sister Carrie was the first masterpiece of the American naturalistic movement in its grittily factual presentation of the vagaries of urban life and in its ingenuous heroine, who goes unpunished for her transgressions against conventional sexual morality. Dreiser does not forget the basic principles of his naturalism. On the one hand, the author says that "the world only moves forward because of the services of the exceptional individual". But on the other hand, Hurstwood is also a "chessman" of fate. Like Carrie, her success is mostly the result of chance. Indeed, though turn-of-the-century readers found Dreiser's point of view crude and immoral, his influence on the fiction of the first quarter of the century is perhaps greater than any other writer's.

\subsection{Hemingway}

Hemingway (1899-1961) was also one of the outstanding American writers with naturalistic tendency. He was known as what Gertrude Stein had called "a lost generation." His works have sometimes been read as an essentially negative commentary on a modern world filled with sterility, inevitable failure and death, which is just the view of naturalism. His primary concern was an individual's "moment of truth," and his fascination with the threat of physical emotional, or psychic death is reflected in his lifelong preoccupation with stories of war $A$ Farewell to Arms, and For Whom the Bell Tolls. Hemingway's stature as a writer was confirmed with the publication of A Farewell to Arms, which portrayed a farewell both to war and to love. Hemingway had rejected the romantic ideal of the ultimate unity of lovers, suggesting instead that all relationship must end in death. The Old Man and the Sea centered upon Santiago, an aging Cuban fisherman who struggled with a giant marlin and sharks far out in the Gulf Stream. He ended up with a defeat that the sharps ate the giant marlin which he pulled onto his skiff's side and stabbed with all his strength. From portraying Santiago's images, the novel embodies obviously environmental determinism. Human beings can react toward the exterior but they are helpless before these forces, men and women are overwhelmed by the force of nature. Yet to Hemingway, man's great achievement is to show grace under pressure. There is no another American influence the American people more than Ernest Hemingway. The inside of Hemingway's books, is the spirit of the whole nation. He has great influence on his fellow authors, such as J. D. Salinger, Hunter S. Thompson, Elmore Leonard,etc.

\section{Conclusion}

Naturalist fiction in the United States often concentrated on the non-Anglo, ethnically marked inhabitants of the growing American cities, many of them immigrants and most belonging to a class-spectrum ranging from the destitute to the lower middle-class. Writers were skeptical towards, or downright hostile to, the notions of bourgeois individualism that characterized realist novels about middle-class life. Most naturalists demonstrated a concern with the animal or the irrational motivations for human behavior, sometimes manifested in connection with sexuality and violence.

In America naturalism had been shaped by the war, by the social upheavals that undermined the comforting faith of an earlier age, and by the disturbing teachings of Charles Darwin. Darwinism seemed to stress the animality of man, to suggest that he was dominated by the irresistible forces of evolution (Wu Weiren, 1990, p.8) The pessimism and deterministic ideas of naturalism pervaded the works of such writers as Frank Norris, jack London, Theodore Dreiser and Hemingway. Their detailed descriptions of the lives of the down-trodden and the abnormal, their frank treatment of human passion and sexuality and their portrayal of men and women overwhelmed by the blind forces of nature still exert a powerful influence on modern writer.

\section{References}

Hemingway. (1999). The Old Man and the Sea. Jiangsu: Jiangsu Yilin Press.

Hemingway. (2004). A Farewell to Arms. Xi'an : World Publishing Corporation. 
http://en.wikipedia.org/wiki/Naturalism_(literature).

http://www.gradesaver.com/sister-carrie/e-text/sources/.

Lin, Xianghua. A Dictionary of Western Literary Critical Terms. Shanghai: Shanghai Academy of Social Sciences.

London, Jack. (1994).The Call of Wild [M]. Beijing: Foreign Language Teaching and Research Press.

Peter conn. (1989). Literature in American. Cambridge University Press.

Sinclair Lewis. Nobel Lecture, December 12, 1930.

The Webster's Dictionary of the English Language.1989 Lexicon Publications.

Wu, Weiren. (1990). History and Anthology of American Literature Volume 2. Foreign Language Teaching and Research Press.

zhang, chong. (2008). Anthology of American Literature. Shanghai: Fudan University Press.

Zola, (1988). Naturalism [M]. Beijing: China Social Sciences Press. 